\title{
Urban consumption in modern Iran (Case study: City of Zanjan)
}

\author{
Consumo urbano no Irã moderno (Estudo de caso: cidade \\ de Zanjan)
}

Mona Fathalibiglou [a], Mohammad Taghi Pirbabaei [a] [D]

[a] Tabriz Islamic Art University, Faculty of Architecture and Urbanism, Tabriz, Iran

How to cite: Fathalibiglou, M., \& Pirbabaei, M. T. (2021). Urban consumption in modern Iran (Case study: City of Zanjan). urbe. Revista Brasileira de Gestão Urbana, v.13, e20190295. https://doi.org/10.1590/2175-

3369.013.e20190295

\begin{abstract}
Numerous studies have been conducted on consumption within urban spaces. However, how people from different socio-economic classes consume urban spaces has not been sufficiently studied specially in Iran. To fill these gaps, the distinguishing feature of this paper is providing answer to how people consume urban spaces in everyday life and focusing on understanding style of consumption in urban spaces considering the dominant category of purchasing, taking heed of the various socio-economic classes in lieu of merely sex issues in modern life. To this end, abductive research strategy was employed. Using data encoding method in Grounded Theory, the results were analyzed which indicated four patterns for urban consumption and 24 consumption spaces in Zanjan. These consumption spaces were studied based on six styles of consumption. The results of the study indicated symbolic consumption is the most prominent style of consumption and that in many consumption spaces in Zanjan, different socio-economic classes are segregated and people from certain socioeconomic classes are mostly present and the presence of people from other classes is insignificant. While social mixing was seen in some spaces, it was found that in urban space consumption people associate meanings with the spaces which convey their desired identities.
\end{abstract}

Keywords: Urban consumption. Consumption patterns. Social life. Modern Iran.

\section{Resumo}

Numerosos estudos têm sido realizados sobre o consumo em espaços urbanos. No entanto, como pessoas de diferentes classes socioeconômicas consomem espaços urbanos não foi suficientemente estudado, especialmente no Irã. Para preencher essas lacunas, este artigo está dando respostas sobre como as pessoas consomem os espaços urbanos no cotidiano e focando na compreensão do estilo de consumo nos espaços urbanos considerando a categoria dominante de compra, levando em consideração as várias classes socioeconômicas em vez de questões meramente sexuais na vida moderna. Para este fim, a abordagem de abdução foi usada neste artigo. Os resultados

MF is PhD candidate in Islamic Urbanism, e-mail: m.biglou@tabriziau.ac.ir

MTP is professor of Urban Design, PhD in Architecture, e-mail: pirbabaei@tabriziau.ac.ir (corresponding author) 
indicaram que existem quatro padrões de consumo urbano e vinte e quatro espaços de consumo na cidade de Zanjan usando o método de codificação de dados na Teoria Fundamentada. Esses espaços de consumo foram estudados a partir de seis estilos de consumo. Os resultados do estudo indicaram que o consumo simbólico é o estilo de consumo mais proeminente e que, em muitos espaços de consumo em Zanjan, há a separação de diferentes classes socioeconômicas e há presença de pessoas de certas classes socioeconômicas em determinados espaços enquanto a presença de pessoas de outras classes é insignificante. Além disso, embora a mistura social seja observada em alguns espaços, os resultados indicaram que, no consumo dos espaços urbanos, as pessoas associam significados com os espaços que indicam a identidade desejada.

Palavras-chave: Consumo urbano. Padrões de consumo. Vida social. Irã moderno.

\section{Introduction}

The role played by consumption in the expansion of both modern and postmodern cities has long been the center of attention by scholars (e.g. Veblen, 1965; Simmel, 1957; Bourdieu, 1984; Zokin, 1982; Knox, 1987; Soja, 1989; Harvey, 1989). The essentials required by life urge us to be consumers to some extent. Not only do we consume materials but also, we consume spaces. That is why investigating consumption within urban environments has always been an intriguing topic for scholars. Miles (2010, p. 1) declares our cities are what and where we consume. In essence, the city is in fact nothing more than a space for consumption in which we apparently express ourselves as citizens of a consumer society. While the intervening years have witnessed a steady stream of excellent work in multiple disciplines, not many studies are performed on the differences between men and women when it comes to urban consumption.

Fainstein and Servon (2005) maintain that for most of the history of planning the subject of differences among people was invisible. True to their roots in the modernist tradition, planners sought a universalizing approach that did not distinguish among persons based on their group affiliations. And it is even more eminent in urban consumption studies.

The present study demonstrates the ways in which men and women from different classes and ages become consumers; all of which work to shape and reproduce people's consumption decisions and identities in modern Iran. Iran is located in Middle East with constitutional, Islamic theocracy. Its official religion is the doctrine of the Twelver Shia Islam. In Iran, women are required to wear hijab and they also face certain legal and cultural constraints such as being segregated from men in some places and also certain cultural and social expectations. Studying how men and women consume urban spaces in modern Iran is considered a necessity due to its unique cultural and political features as well as dearth of an analogous research in this realm (So far, few studies have been conducted in this field in Iran, some of which have remained large-scale and do not examine tangible consumption patterns in urban spaces (Hajizadeh \& Yusefi, 2013), or simply study a specific urban space such as a shopping centers (Mohammadpour \& Bahmani, 2010)). This study points to some of the ways in which it is important and appropriate to develop group-informed perspectives of consumption (sex, age and socio-economic class) and make women visible not only as subjects of study but also as active participants in urban planning processes.

\section{Literature review}

Jayne (2006) believes modern city mass consumption was combined with mass production to produce sustained economic growth and widespread material advancement. But, the economy of the postmodern city is less based on production and consumption of goods and more on the production and consumption of culture. The significance of culture is linked to the rise of a symbolic economy concerned with making and distributing images (Scott, 2000).

Consumption has been described as being simultaneously about the 'selection, purchase, use, reuse and disposal of goods and services' (Campbell, 1995, p. 104); as 'comprising a set of practices which permit people to express self-identity, to mark attachment to social groups, to accumulate resources, to exhibit 
social distinctions, to ensure participation in social activities' (Warde, 1997, p. 304); and as central to the ways in which we construct, experience, interpret and use spaces and places (Urry, 1995, in Jayne, 2006, p. 20). As argued by many (e.g. Castree, 2003; Massey, 2005; Thrift, 2003), space and place are not merely the stage on or containers in which we act out our social and material lives, but rather are actively negotiated, created and changed through all manner of relationships (Goodman et al., 2010, p. 13).

What distinguishes modern from traditional consumer behavior is the ability of modern consumers to generate endless new wants, whilst also being attracted to, rather than fearful of, novelty (Campbell, 1987, p. 77).

Studying consumption: Class, has been a prominent concern in consumption studies. Influenced by Bourdieu's thinking (1984) the sociological literature has increasingly emphasized on the importance of consumption in shaping patterns of social location and social relations in contemporary societies (Featherstone, 1995; Lunt and Livingstone, 1992; Miller, 1995; Slater, 1997) and its significance for selfidentity (Giddens, 1991; Bauman, 1987; Friedman, 1994).

Valentine (1989, in Jayne, 2006, p. 107) believed "men and women inhabit the same areas; however, despite this co-presence, men and women not only use cityscapes in different ways but also experience and perceive them differently". Most studies that take women's participation in consumption spaces into account only pay attention to commercial consumption spaces such as department stores, shopping centers, market places and so on. (e.g. Domosh, 1996; Glennie \& Thrift, 1992; Jackson, 1997; Sandhu \& Paim, 2016). They argue that "women constitute the major class of consumers in modern society. Consumption is a defining characteristic of femininity and has played an important role in women's social and economic position and relationship with the city" (Domosh, 1996). But, are all consumption spaces commercial? If not, what is the role of women in non-commercial consumption spaces?

Styles of consumption: Six styles of consumption are outlined in following text: 1. Passive Consumption: In this approach, the consumer is assumed to be passive and consumption is considered a kind of manipulation by power. The goods and experiences that are consumed have become pre-packaged goods and experiences that have been coded to generate and receive specific answers (Bocock, 2008). 2. Conspicuous Consumption: The most important issue in this concept is that consumerism shows financial power, status, and class in the society while making others jealous (Firat et al., 2013, p. 185). 3. Symbolic Consumption: Symbolic Consumption comprises of evaluation of products based on their symbolic values, purchase and consumption. People would like to specify characteristics of their needs and desires or communicate via consumption (Firat et al., 2013, p. 186). 4. Sacred consumption: The distinctive feature of sacred consumption is to contain products and services which are served with some degree of respect and awe. Sacred consumption may be related to religious beliefs or not, but most probably people tend to respect holy elements and events as sacred (Firat et al., 2013, p. 187). 5. Innovative Consumption: De Certeau (1998) does not consider consumers passive. According to him, consuming means making and making is also a kind of hidden production. De Certeau assumes that users make countless changes in order to adapt things to their interests within the dominant economic-cultural order. 6. Fun Morality: In modern consumerism, you have to try everything, for consumerist man is haunted by the fear of 'missing' something, some form of enjoyment or the other. It is no longer desire, or even 'taste', or a specific inclination that are at stake, but a generalized curiosity, driven by a vague sense of unease - it is the 'fun morality' or the imperative to enjoy oneself, to exploit one's potential for thrills, pleasure or gratification to the full (Baudrillard, 1998, p. 80).

\section{Research method}

In order to study the concepts and categories related to urban space consumption, abductive research strategy (see Blaikie, 2007) was used in present study. This research method involves presenting theories derived from social actors, their meanings and later extraction of categories and concepts which can be the bases for understanding and explanation of an existing enquiry. 
In this study, grounded theory was used for data analysis. Blaikie believes that grounded theory is the most noticeable scientific method within abductive research strategy (Blaikie, 2007). Analysis in grounded theory is the act of taking data, thinking about it, and denoting concepts to stand for the analyst's interpretation of the meaning intended by the participant (Corbin \& Strauss, 2015)

For data analysis, all the interviews were transcribed and for their analysis, grounded theory was used. In grounded theory coding technique is used to analyze the data. Coding is defined as "denoting concepts to stand for data". Coding process can be done in three steps: Open coding, axial coding and selected coding (Corbin \& Strauss, 2015).

Open Coding: Open coding is used as the first level for identification. It is an analytical process through which concepts and categories with their specification and denotations are recognized. In open coding of data, the data is broken into smaller meaningful phrases, labeled and analyzed and changed into concept and category.

Axial Coding: After open coding, the researcher must conduct axial coding. In axial coding, it is intended to compose and combine the data with establishing the relationship between categories and subcategories to find their dimensions and specifications.

Selective Coding: The last stage of coding is selective coding in which one core category is selected which connects all other categories in a comprehensive way.

Our analysis is based on data collected from 2018 to 2019 for a cross-Zanjan study investigating the consumption of urban spaces. The abductive research strategy and grounded theory on which this article is based was designed to explore the answer to the following questions: at the outset, how people (coming from various socioeconomic statuses) tend to consume urban spaces and second, how consumption spaces influence what people do. The study was designed to consist of two stages, first observation and field work conducted in consumption spaces and second, interview. In some cases, the key informants interview technique and in some other cases a gradual sampling technique has been used. The selected interview pattern was open-ended and semi-structured interviews, and completion of sampling and interviewing has also happened with the achievement of theoretical saturation. Interviews were completed with 145 participants (71 males and 74 females) in 16 mahalleh (neighborhood) across Zanjan. Drawing on the interviews with males and females of various ages and from various class backgrounds living in Zanjan, their consumption patterns and spaces were identified and these patterns were then put in four categories by the researchers based on their functional nature (commercial consumption, recreational consumption, religious consumption and natural environment consumption).

To ensure that people from all class backgrounds were studied, the result of Davoodi's research (2013) on "Spatial pattern of habitation of different socio-economic classes in Zanjan" was used. In her research, she classifies Zanjan urban mahalleh based on 5 indicators, namely the price of residential units, the size of plots, the plot pattern, the formality and informality of habitation and finally the social and cultural capital of residents into four groups (Low income /Middle class/Parvenu and prosperous class). From each class mahalleh, 4 were chosen to conduct detailed studies. Also, 30 interviews were done in downtown Zanjan. In some consumption patterns, there was a clear difference between different age groups. Therefore, if there was such a difference, the data for each age group were presented separately (child: 2-11 years old, teenager: 12-19, young: 20-35, adult: 36-59 and old: 60 and older). Next, interviews were transcribed and coded using open coding, axial coding and selective coding. The results were summarized in the form of tables. Also, only key findings are presented in a paragraph before each table.

The observation technique (participant observation) in conjunction with the interview technique allowed the researchers to understand the manner in which the public and semi-public spaces were consumed. To document the results of observations, tabs and observation plans that have been structured in varying degrees and field notes have been used. The analysis of collected data was also carried out during a process in which interpretation and compilation were interconnected (details of the number of spaces which were observed are presented in table1). 
The results of the study are summarized into four tables (tables 4, 6, 8 and 10). For each style of consumption, a specific code is given. Moreover, the coding system for detailed study of consumption spaces is represented in Table 2.

Table 1 - The number of spaces which were observed in the present research

\begin{tabular}{lllll}
\hline $\begin{array}{l}\text { Consumption } \\
\text { pattern }\end{array}$ & $\begin{array}{l}\text { Commercial } \\
\text { consumption }\end{array}$ & $\begin{array}{l}\text { Recreational } \\
\text { consumption }\end{array}$ & $\begin{array}{l}\text { Religious } \\
\text { consumption }\end{array}$ & $\begin{array}{l}\text { Natural environment } \\
\text { consumption }\end{array}$ \\
\hline Number of space & 36 & 25 & 15 & 24 \\
\hline
\end{tabular}

Source: Data collected by the authors field research (2019).

Table 2 - Coding system for detailed study of consumption spaces

\begin{tabular}{lllllll}
\hline $\begin{array}{l}\text { Styles of } \\
\text { Consumption }\end{array}$ & $\begin{array}{l}\text { Passive (Non- } \\
\text { conspicuous) } \\
\text { consumption }\end{array}$ & $\begin{array}{l}\text { Conspicuous } \\
\text { consumption }\end{array}$ & $\begin{array}{l}\text { Symbolic } \\
\text { consumption }\end{array}$ & $\begin{array}{l}\text { Sacred } \\
\text { consumption }\end{array}$ & $\begin{array}{l}\text { Innovative } \\
\text { consumption }\end{array}$ & $\begin{array}{l}\text { Fun } \\
\text { morality }\end{array}$ \\
\hline Code & (NCC) & (CC) & (SyC) & (SaC) & (IC) & (FM) \\
\hline
\end{tabular}

Source: Adopted from Bocock (2008), Firat et al. (2013), De Certeau (1998), and Baudrillard, (1998).

\section{Case study background}

Zanjan city, the capital of Zanjan province containing a population of 430, 871 people in 2016 (The population of Zanjan has increased more than 8.2 times in a 55-year period), is located in the northwest of Iran, 328 kilometers away from Tehran, whose area was virtually 156 square kilometers in 2016 . The average age is 30.49 and sex ration is 101.84 .122922 people are under 20 years old, 267396 people are between 20 and 60 years old and finally 40553 people are over 60 years old. (Zanjan municipality, 2016). The city is located about 20 kilometers south of the Qaflankuh Mountain Range. In terms of ethnic composition, the people of Zanjan are a mixed group of Aryan and Georgian tribes and the tribes of the Khamseh tribe. The language of the people of Zanjan is Azerbaijani Turkish, with a Zanjani dialect. The religion of most of the people of Zanjan is Islam, and the people of Zanjan (which is considered a religious city) are considered followers of the Shia school (Zanjan Road and Urban Development Organization, 2019).

\section{Findings}

Drawing on the interviews with the participants and field works, four patterns of urban consumption were identified in Zanjan.

\section{Commercial Consumption}

\section{Shopping:}

Traditional Bazaar of Zanjan, commercial streets, shopping centers, department stores and thrift shops are the main consumption spaces for commercial consumers. On the whole, it could be concluded that each class has its own consumption spaces. Whereas, the financial difficulties of the lower middle class and their mobility issues decrease their presence in some commercial spaces as well.

Based on the interviews, in their everyday lives, women have to deal with a range of invasions of their privacy in the urban crowd, from personal comments and inappropriate gestures to more serious incidents of physical violence while these incidents rarely happen in semi-public spaces due to their security features. As a result, women typically feel safer in malls and department stores and spend time for shopping more comfortably; yet, it certainly does not mean that they have less presence in commercial public spaces. In addition to purchasing, they also take pleasure in looking at how commodities look, enjoy ambience of the shops and the public social life. On the other hand, the pattern of shopping for men is more of an essential 
purchase. This indicates that men go shopping only if they need to buy something. Last but not least, commercial spaces are one of the most important social spaces for teenagers and the young generations (girls and boys), as a place to look or be looked at and be in contact with the opposite sex.

\section{Food/Drink Consumption:}

Cafes, teahouses, restaurants and fast-food restaurants are the main consumption spaces for food/drink consumers. The results of the interviews point to the fact that all socio-economic classes are present in the consumption spaces of this category. But since in this category of spaces people have to spend money (you cannot go to a restaurant without ordering anything), the presence of low-income group in these spaces is severely reduced and such spaces are extremely segregated which means each of the socioeconomic classes has its own special consumption spaces, and aside from the prices, there are many visual indications (the interior design, the appearance of customers and workers, the rituals of consuming that space, for example how to order food and so on.) that discourage individuals from being in a heterogeneous space. One of people's (from middle class) favorite activities is to go to famous restaurants (which are usually targeted by the wealthy), this usually happens once in a few months. But almost always these people are easily identified due to lack of their socio-cultural capital.

Cafes, on the other hand, are places where usually young girls and boys meet and socialize, a place where families rarely attend. Cafes are where youngsters secretly date while experiencing some kind of fear because Guidance Patrol may ask them to clarify their relationship and if they are not officially related, legal consequences would await them. But it does not happen very often lately. Besides, youngsters dare take their chances and socialize with the opposite sex in these spaces anyway.

Teahouses, on the other hand, are extremely gendered spaces. There are very few teahouses citywide in which women are allowed to enter. These are places in which people usually smoke hookah. More detailed results about commercial consumption are presented in table 4 .

Table 3 - A sample of selective coding for interviews regarding Bazaar of Zanjan

\begin{tabular}{|c|c|c|c|c|c|}
\hline \multirow{2}{*}{ Spaces } & \multirow{2}{*}{ Sex } & \multicolumn{4}{|l|}{ Socio-economic classes } \\
\hline & & Low-income class & Middle-class & Parvenu & Prosperous class \\
\hline \multirow[b]{2}{*}{$\begin{array}{l}\text { Traditional } \\
\text { Bazaar of } \\
\text { Zanjan }\end{array}$} & Male & \multirow{2}{*}{$\begin{array}{l}\text { Visiting the Bazaar from } \\
\text { inside and outside the } \\
\text { city for essential } \\
\text { shopping }\end{array}$} & \multirow{2}{*}{$\begin{array}{l}\text { strolling and } \\
\text { leisure shopping } \\
\text { from Bazaar }\end{array}$} & \multirow[b]{2}{*}{$\begin{array}{l}\text { not going to } \\
\text { the Bazaar }\end{array}$} & \multirow{2}{*}{$\begin{array}{l}\text { Experiencing the } \\
\text { historical and } \\
\text { traditional space of } \\
\text { Bazaar }\end{array}$} \\
\hline & Female & & & & \\
\hline
\end{tabular}

Source: Final stages of data analysis through grounded theory.

Table 4 - Commercial consumption in different classes and sexes

\begin{tabular}{|c|c|c|c|c|c|}
\hline \multirow[b]{2}{*}{ Spaces } & \multirow[b]{2}{*}{ Sex } & \multicolumn{4}{|c|}{ Socio-economic classes } \\
\hline & & $\begin{array}{l}\text { Low-income } \\
\text { class }\end{array}$ & Middle-class & Parvenu & Prosperous class \\
\hline $\begin{array}{l}\text { Traditional } \\
\text { Bazaar of } \\
\text { Zanjan }\end{array}$ & $\begin{array}{l}\text { Male } \\
\text { Female }\end{array}$ & (NCC) & (SyC) & (Absent) & (FM) \\
\hline $\begin{array}{l}\text { Commercial } \\
\text { streets }\end{array}$ & $\begin{array}{l}\text { Male } \\
\text { Female }\end{array}$ & (NCC) & $\begin{array}{l}\text { (SyC \& IC) } \\
\text { teen boys } \\
\text { (NCC \& SyC) } \\
\text { Women } \\
\text { (SyC \& IC) } \\
\text { teen girls }\end{array}$ & $\begin{array}{l}\text { (SyC \&CC) } \\
\text { teen boys } \\
\text { (NCC \& SyC) } \\
\text { Women } \\
\text { (SyC \&CC) } \\
\text { teen girls }\end{array}$ & $\begin{array}{l}\text { (SyC) } \\
\text { (NCC \& SyC) }\end{array}$ \\
\hline
\end{tabular}


Table 4 - Commercial consumption in different classes and sexes

\begin{tabular}{|c|c|c|c|c|c|}
\hline \multirow[b]{2}{*}{ Spaces } & \multirow[b]{2}{*}{ Sex } & \multicolumn{4}{|c|}{ Socio-economic classes } \\
\hline & & $\begin{array}{l}\text { Low-income } \\
\text { class }\end{array}$ & Middle-class & Parvenu & Prosperous class \\
\hline \multirow{6}{*}{$\begin{array}{l}\text { Shopping } \\
\text { centers }\end{array}$} & Male & (Absent) & (SyC \& IC) & (SyC \&CC) & (SyC) \\
\hline & & & $\begin{array}{l}\text { young and teen } \\
\text { boys }\end{array}$ & $\begin{array}{l}\text { young and teen } \\
\text { boys }\end{array}$ & young and teen boys \\
\hline & Female & (SyC) & (NCC \& SyC) & (NCC \& SyC) & (NCC \& SyC) \\
\hline & & & Women & Women & Women \\
\hline & & & (SyC \& IC) & (SyC \&CC) & (SyC \& CC) \\
\hline & & & teen girls & teen girls & teen girls \\
\hline \multirow{3}{*}{$\begin{array}{l}\text { Department } \\
\text { stores }\end{array}$} & Male & $(\mathrm{NCC})$ & adult men & adult men & adult men \\
\hline & & & $\begin{array}{l}\text { accompanying } \\
\text { their family }\end{array}$ & $\begin{array}{l}\text { accompanying } \\
\text { their family }\end{array}$ & $\begin{array}{l}\text { accompanying their } \\
\text { family }\end{array}$ \\
\hline & Female & (SyC \& NCC) & (SyC \& NCC) & (NCC) & (NCC) \\
\hline \multirow{3}{*}{$\begin{array}{l}\text { Cheap sales } \\
\text { stores }\end{array}$} & Male & adult men & adult men & (Absent) & (Absent) \\
\hline & & $\begin{array}{l}\text { accompanying } \\
\text { their family }\end{array}$ & $\begin{array}{l}\text { accompanying } \\
\text { their family }\end{array}$ & & \\
\hline & Female & (NCC \& SyC) & (NCC) & (Absent) & (Absent) \\
\hline \multirow[t]{4}{*}{ Cafes } & Male & (Absent) & (SyC) & (SyC \& CC) & \\
\hline & & & young boys & young boys & \\
\hline & Female & (Absent) & (SyC) & (SyC \& CC) & \\
\hline & & & young girls & young girls & \\
\hline \multirow[t]{2}{*}{ Teahouses } & Male & (SyC) & & (SyC \& CC) & \\
\hline & Female & (SyC) & young girls & (SyC \& CC) & (Absent) \\
\hline \multirow[t]{2}{*}{ Restaurants } & Male & (NCC) & (NCC \& SyC) & (CC \& SyC) & (NCC \& SyC) \\
\hline & Female & (NCC) & & & \\
\hline \multirow{2}{*}{$\begin{array}{l}\text { Fast food } \\
\text { restaurants }\end{array}$} & Male & (NCC) & (NCC \& SyC) & (NCC \& SyC) & (NCC \& SyC) \\
\hline & Female & (Absent) & & & \\
\hline
\end{tabular}

Note: NCC stands for passive (non-conspicuous) consumption; CC stands for conspicuous consumption; SyC stands for symbolic consumption; SaC stands for sacred consumption; IC stands for innovative consumption and FM stands for fun morality. Source: Final stages of data collected and coded by the authors field research (2019) analyzed through grounded theory.

\section{Recreational Consumption}

Gaming centers, amusement parks, venues for music performance, exhibitions and festivals, cinemas and theaters are the main consumption spaces for recreational consumers. In this category, likewise, the lower middle class has been removed from many consumer spaces due to monetary restraints. Gaming centers are men's spaces for teenage boys from the lower middle class. Regarding music concerts it should be noted that audiences are required to sit in a theater hall, on rows of chairs and listen to the music, they can co-sing the songs but they are not allowed to dance at all. The most frequent audience of concerts are young people and teenagers, while exhibitions and festivals are almost family-friendly consumption spaces.

Regarding exhibition and festival venues, it is worth mentioning that people belonging to the middleclass are interested in attending all exhibitions and festivals because of the busy, lively and rich social environment. This is while upper middle-class people are only absorbed to the topic of certain exhibitions and festivals as if they are generally dissatisfied with the crowded environment and the heterogeneous social mix of participants. Lastly, cinema finds most of its audience among the middle class and theater among the middle and upper class. Surprisingly, the Parvenu shows reluctance to attend the theater.

Sport Consumption:

Gyms, stadiums and pools are the main consumption spaces for sport consumers. Here are two points to be noted. Initially, consumption spaces related to sports are gendered spaces. Women and men are completely segregated from one another and law enforcement agents even prevent women's entrance to 
stadiums to watch men's games or matches. In these types of spaces, as in previous examples, the presence of a low income class is very low. Also, among men, young people tend to display more athleticism than adults, and women are more likely to go to swimming pools and gyms (overall, women's participation in sports activities is lower than men). Gym's popularity among young women and men is ascending day by day not because they like to work out but because they are obsessed with slenderness. More detailed results about recreational consumption are presented in table 6.

Table 5 - A sample of selective coding for interviews regarding music concerts

\begin{tabular}{|c|c|c|c|c|c|}
\hline \multirow{2}{*}{ Spaces } & \multirow{2}{*}{ Sex } & \multicolumn{4}{|l|}{ Socio-economic classes } \\
\hline & & Low-income class & Middle-class & Parvenu & Prosperous class \\
\hline $\begin{array}{l}\text { Music } \\
\text { concerts }\end{array}$ & $\begin{array}{l}\text { Male } \\
\text { Female }\end{array}$ & $\begin{array}{l}\text { Interest in participating in upper- } \\
\text { middle-class experiences } \\
\text { absence }\end{array}$ & \multicolumn{3}{|c|}{$\begin{array}{l}\text { Establishing their position on their own class or } \\
\text { upper class / Interest in new and varied } \\
\text { entertainments and fear of losing an enjoyable } \\
\text { experience }\end{array}$} \\
\hline
\end{tabular}

Source: Final stages of data analysis through grounded theory.

Table 6 - Recreational consumption in different classes and sexes

\begin{tabular}{|c|c|c|c|c|}
\hline \multirow{2}{*}{ Spaces } & \multirow{2}{*}{ Sex } & \multicolumn{3}{|c|}{ Socio-economic classes } \\
\hline & & Low-income class & Middle-class & Prosperous class \\
\hline \multirow{2}{*}{ Music concerts } & Male & (SyC) & \multicolumn{2}{|l|}{ (FM \& SyC) } \\
\hline & Female & (Absent) & \multicolumn{2}{|l|}{ teenagers and youngsters } \\
\hline \multirow{3}{*}{ Gaming centers } & Male & (NCC \& FM) & (NCC \& SyC) & \multirow{3}{*}{ (Absent) } \\
\hline & & teenage boys & teenage boys & \\
\hline & Female & (Absent) & & \\
\hline \multirow{2}{*}{$\begin{array}{l}\text { Amusement } \\
\text { Parks }\end{array}$} & Male & (NCC \& SyC) & adult men/women & \multirow{2}{*}{$\begin{array}{l}\text { adult men/women } \\
\text { accompanying their children (in } \\
\text { shopping centers) }\end{array}$} \\
\hline & Female & (NCC) & $\begin{array}{l}\text { accompanying their } \\
\text { children (in parks) } \\
\text { adult men }\end{array}$ & \\
\hline \multirow[t]{2}{*}{$\begin{array}{l}\text { Exhibitions and } \\
\text { festivals }\end{array}$} & Male & (Absent) & $\begin{array}{l}\text { accompanying their } \\
\text { family } \\
\text { adult women }\end{array}$ & \multirow[t]{2}{*}{$\begin{array}{l}\text { Their presence depends on the } \\
\text { theme of the exhibition }\end{array}$} \\
\hline & Female & (SyC) & $\begin{array}{l}\text { accompanying their } \\
\text { friends or family }\end{array}$ & \\
\hline \multirow{3}{*}{ Cinemas } & Male & (SyC) & & \multirow{3}{*}{ (SyC \& FM) } \\
\hline & TVICIE & young boys & (SyC \& FM) & \\
\hline & Female & (SyC) & & \\
\hline \multirow{2}{*}{ Theaters } & Male & (Absent) & (SyC) & \multirow[b]{2}{*}{ Only art lovers } \\
\hline & Female & & Only art lovers & \\
\hline \multirow[t]{3}{*}{ Gyms } & Male & (SyC) & $\begin{array}{l}\text { teenage and young } \\
\text { men }\end{array}$ & $\begin{array}{l}\text { (SyC, CC \& FM) } \\
\text { teenage and young men }\end{array}$ \\
\hline & Female & (Absent) & (SyC) & (SyC, CC \& FM) \\
\hline & Male & (SyC) & & (SyC) \\
\hline \multirow[t]{2}{*}{ Stadiums } & Female & (Absent) & (SyC) & $\begin{array}{l}\text { (SyC) } \\
\text { in women onlv agmes }\end{array}$ \\
\hline & & & in women only games & in women only games \\
\hline \multirow[b]{2}{*}{ Pools } & Male & & (SyC) & \multirow{2}{*}{$\begin{array}{l}\text { (SyC, CC \& FM) } \\
\text { in men/women only pools }\end{array}$} \\
\hline & Female & (Absent) & $\begin{array}{l}\text { in men/women only } \\
\text { pools }\end{array}$ & \\
\hline
\end{tabular}

Note: NCC stands for passive (Non-conspicuous) consumption; CC stands for conspicuous consumption; SyC stands for symbolic consumption; SaC stands for sacred consumption; IC stands for innovative consumption and FM stands for fun morality. Source: Final stages of data collected and coded by the authors field research (2019) analyzed through grounded theory. 


\section{Religious Consumption}

Religious events (marches) ${ }^{1}$, Molodi $^{2}$ singing, prayer ceremonies and Nazri3 ${ }^{3}$ distribution are the most popular types of religious consumption. Since the Iranian government is a religious government, religion and religious patterns of consumption are quite political in Iran. The results of this study suggest that there is a small difference between patterns of religious consumption in different classes and sexes. About religious consumption of spaces, it is worth asserting that, Molodi singing and prayer ceremonies are extremely segregated which means each of the socio-economic classes has its own special spaces (these events can be held in mosques or in private spaces), and there are many visual indications (the rituals, the dress code and so on) that discourage individuals from being in a heterogeneous space, albeit no one would dare stop anyone from attending such ceremonies and they are open to public. Only at religious events (marches), different social classes peacefully and willingly stand next to each other.

Religious consumption of space is very difficult for non-Shia religions, if not impossible. These ceremonies are held entirely privately and secretly. More detailed results about religious consumption are presented in table 8 .

Table 7 - A sample of selective coding for interviews regarding religious events

\begin{tabular}{|c|c|c|c|}
\hline \multirow{2}{*}{$\begin{array}{l}\text { Consumption } \\
\text { patterns }\end{array}$} & \multirow[t]{2}{*}{ Sex } & \multicolumn{2}{|l|}{ Socio-economic classes } \\
\hline & & Low-income class & Prosperous class \\
\hline Religious events & $\begin{array}{l}\text { Male } \\
\text { Female }\end{array}$ & $\begin{array}{l}\text { Sincere religious belief / } \\
\text { The symbolic nature of } \\
\text { participating in this } \\
\text { ceremony / Interest in } \\
\text { gaining new experiences }\end{array}$ & $\begin{array}{l}\text { Sincere religious belief / The symbolic nature of } \\
\text { participating in this ceremony }\end{array}$ \\
\hline
\end{tabular}

Source: Final stages of data analysis through grounded theory.

Table 8 - Religious consumption in different classes and sexes

\begin{tabular}{|c|c|c|c|c|c|}
\hline \multirow{2}{*}{$\begin{array}{l}\text { Consumption } \\
\text { patterns }\end{array}$} & \multirow[t]{2}{*}{ Sex } & \multicolumn{4}{|c|}{ Socio-economic classes } \\
\hline & & Low-income class & Middle-class & Parvenu & $\begin{array}{l}\text { Prosperous } \\
\text { class }\end{array}$ \\
\hline $\begin{array}{l}\text { Religious events } \\
\text { (marches) }\end{array}$ & $\begin{array}{l}\text { Male } \\
\text { Female }\end{array}$ & (SaC \& SyC\& FM) & (SaC \& SyC) & & \\
\hline Molodi singing & $\begin{array}{l}\text { Male } \\
\text { Female }\end{array}$ & $\begin{array}{l}\text { (SaC \& SyC) } \\
\text { in men/women only }\end{array}$ & ceremonies & $\begin{array}{l}\text { (SaC \& S) } \\
\text { in men/W }\end{array}$ & nly ceremonies \\
\hline $\begin{array}{l}\text { Prayer } \\
\text { ceremonies }\end{array}$ & $\begin{array}{l}\text { Male } \\
\text { Female }\end{array}$ & & & & \\
\hline Nazri distribution & $\begin{array}{l}\text { Male } \\
\text { Female }\end{array}$ & (SaC \& SyC) & & $(\mathrm{SaC} \& \mathrm{~S})$ & \\
\hline
\end{tabular}

Note: NCC stands for passive (Non-conspicuous) consumption; CC stands for conspicuous consumption; SyC stands for symbolic consumption; SaC stands for sacred consumption; IC stands for innovative consumption and FM stands for fun morality. Source: Final stages of data collected and coded by the authors field research (2019) analyzed through grounded theory.

\footnotetext{
${ }^{1}$ The great Hoseyniyeh of Zanjan is famous for its religious march which happens annually on the 8th day of Muharram. The march starts at Great Hoseyniyeh and usually ends with the call to Maghrib Athan at the Imamzadeh of Ebarhim. The population of the march is estimated to be more than 500 thousand people. On this occasion, people mourn the death of their third Imam.

${ }^{2}$ Molodi is a literary piece that has a happy content and is about Ahl al-Bayt.

${ }^{3}$ Nazri is something that is given free of charge in the cause of God (usually foods and drinks).
} 


\section{Natural Environment Consumption}

Urban green spaces and natural environments are the main consumption spaces for natural environment consumers. Green spaces provide peace of mind, entertainment, sports and leisure opportunities for people and a way to avoid the polluted and crowded life of cities. Zanjan enjoys a cold semi-arid climate. As a result, natural consumption activities mostly happen in spring and summer when the weather is pleasant. In fall and winter people usually prefer to drive around.

Although natural environment consumption is limited to only couple of months a year, it has a very significant role in urban social life in this period. The only point that needs to be addressed in this section is that low-income families have a lower participation in natural spaces due to their mobility constraints, which makes women more vulnerable in comparison with men (men of low-income class have less mobility issue because they can drive motorcycle which is cheaper than car, but women can only get driving license for cars and trucks).

Through the analysis of urban green spaces, it was found that these spaces have a class-limited nature and the behavior of low-income groups is more introverted. Like previous consumption patterns, here too, each class has its own green spaces and men and women have similar presence and consumption patterns. There is only one park specific for women in Zanjan. Some women routinely meet with friends and socialize there several times a week, signifying some new-found urban freedoms for women who were previously bound to their domiciles. Yet, detailed study of this park showed that women from upper middle class and prosperous class strongly resist the presence in this place and do not want to be separated from men in yet another urban space. More detailed results about natural environment consumption are presented in table 10.

Table 9 - A sample of selective coding for interviews regarding urban green spaces

\begin{tabular}{|c|c|c|c|c|}
\hline \multirow{2}{*}{$\begin{array}{l}\text { Consumption } \\
\text { patterns }\end{array}$} & \multirow[t]{2}{*}{ Sex } & \multicolumn{3}{|c|}{ Socio-economic classes } \\
\hline & & Low-income class & Middle-class & $\begin{array}{l}\text { Prosperous } \\
\text { class }\end{array}$ \\
\hline $\begin{array}{l}\text { Urban green } \\
\text { spaces }\end{array}$ & $\begin{array}{l}\text { Male } \\
\text { Female }\end{array}$ & $\begin{array}{l}\text { innovative use of } \\
\text { space in order to } \\
\text { form various social } \\
\text { interactions with } \\
\text { acquaintances and } \\
\text { strangers in the green } \\
\text { spaces of the low- } \\
\text { income } \\
\text { neighborhoods }\end{array}$ & $\begin{array}{l}\text { Forming social } \\
\text { interactions with } \\
\text { friends and } \\
\text { acquaintances in } \\
\text { green spaces of the } \\
\text { middle-class } \\
\text { neighborhoods }\end{array}$ & $\begin{array}{l}\text { Use of green space as a } \\
\text { place for running and } \\
\text { cycling and also walking } \\
\text { pets in the green spaces of } \\
\text { the prosperous class } \\
\text { neighborhoods }\end{array}$ \\
\hline
\end{tabular}

Source: Final stages of data analysis through grounded theory.

Table 10 - Natural environment consumption in different classes and sexes

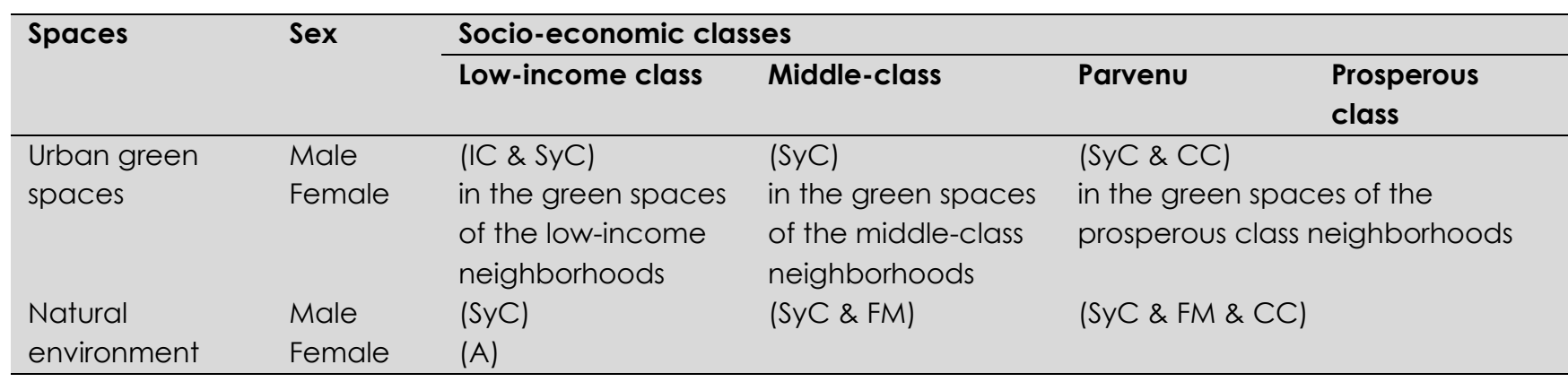

Note: NCC stands for passive (Non-conspicuous) consumption; CC stands for conspicuous consumption; SyC stands for symbolic consumption; SaC stands for sacred consumption; IC stands for innovative consumption and FM stands for fun morality. Source: Final stages of data collected and coded by the authors field research (2019) analyzed through grounded theory. 


\section{Conclusions}

In the conclusion of studies conducted on Zanjan consumption spaces, a few points are worth mentioning which go as follows. At the outset, participation in the contemporary consumer lifestyle for the people of Zanjan, both in public and in semi-public spaces, usually requires spending money (of the 24 consumption spaces studied, access to 13 costs money), which plenty of low income classes do not have the financial ability to do so. As a result, they are absent in many of the consumption spaces and they are marginalized in the rest. It was observed that if low income classes are participating in a consumption pattern, then their consumption space is usually different from other classes (for example, the restaurants or green spaces). In this regard, it appears that men show more resistance than women, and the women belonging to the low-income class are more vulnerable than men in this class (mobility issues). Second, it seems that the middle class is the main contributor to all types of consumption spaces in Zanjan. Parvenus are making every effort to distance themselves from middle- and low-income class with their consumption patterns. People from prosperous class have the most presence in expensive and luxurious spaces, and they are pretty selective about their consumption patterns. Yet, in contrast to the parvenus, they show less resistance to the middle class. Religious events (marches) are the only type of space consumption in which all classes, men and women are equally present.

Studying the role of consumption in the contemporary city and its public social life is a very complex and extensive discussion. The present study tried to structure this broad discussion by defining a specific framework for these studies and conduct a sample study in the city of Zanjan based on this framework. In this framework four patters of consumption (Commercial consumption, Recreational consumption, Religious consumption and Natural environment consumption) and six styles of consumption (Passive (Non-conspicuous) consumption, Conspicuous consumption, Symbolic consumption, Sacred consumption, Innovative consumption and Fun morality) were defined. A summary of consumption styles in different consumption spaces of Zanjan is presented in table 11. As can be seen in this table, the most obvious consumption style in all consumption patterns and among all socio-economic classes is symbolic consumption. Other notable points in this table are the absence of the low-income class in some consumption patterns as well as Non-conspicuous consumption striking out. In addition, conspicuous consumption has been significant among the parvenu class. Finally, religious consumption style is the only consumption style that is common to all socio-economic classes.

The outcomes of the studies indicate that among 24 patterns and consumption spaces studied, in five cases (gyms, stadiums, pools, molodi singing and prayer ceremonies), women and men ought to be entirely segregated, and in two types of space (Gaming Centers and certain tea houses), women's admission is completely verboten. Also, in all consumption spaces (except for women only parks) women are required to wear hijab and relationships between women and men, as mentioned before, have their own rules and limitations. On the whole, it must be mentioned that the present study tried to provide answers to the following questions: how people consume urban spaces in everyday life and how the style of consumption in urban spaces can be understood. Taking these points into account, it was found that in urban space consumption, people associate meanings with the spaces which convey their desired identities. 
Table 11 - Summary of consumption styles in different consumption spaces of Zanjan

\begin{tabular}{|c|c|c|c|c|c|}
\hline \multirow{2}{*}{ Spaces } & \multirow{2}{*}{ Sex } & \multicolumn{4}{|c|}{ Socio-economic classes } \\
\hline & & Low-income class & Middle-class & Parvenu & Prosperous class \\
\hline \multirow{8}{*}{$\begin{array}{l}\text { Commercial } \\
\text { consumption } \\
\text { Recreational } \\
\text { consumption } \\
\text { Religious } \\
\text { consumption } \\
\text { Natural } \\
\text { environment } \\
\text { consumption }\end{array}$} & Male & (NCC) & \multirow{4}{*}{ (SyC) } & \multirow{2}{*}{$(\mathrm{SyC})(\mathrm{CC})$} & (SyC) \\
\hline & Female & (NCC) (SyC) & & & (SyC) (NCC) \\
\hline & Male & (SyC) (A) & & \multirow{2}{*}{ (SyC) (FM) } & \\
\hline & Female & (A) (SyC) & & & \\
\hline & Male & \multirow{2}{*}{$(\mathrm{SaC})(\mathrm{SyC})$} & & \multirow{4}{*}{$(\mathrm{SyC})(\mathrm{CC})$} & \\
\hline & Female & & & & \\
\hline & Male & \multirow{2}{*}{ (SyC) } & & & \\
\hline & Female & & & & \\
\hline
\end{tabular}

Note: NCC stands for passive (non-conspicuous) consumption; CC stands for conspicuous consumption; SyC stands for symbolic consumption; SaC stands for sacred consumption; IC stands for innovative consumption and FM stands for fun morality. Source: Final stages of data collected and coded by the authors field research (2019) analyzed through grounded theory.

\section{References}

Baudrillard, J. (1998), The Consumer Society: Myths and Structures, SAGE Publications Ltd.

Bauman, Z. (1987). Legislators and Interpreters: On Modernity, Postmodernity and Intellectuals. Polity Press.

Blaikie, N. (2007), Approaches to Social Enquiry. Polity Press.

Bocock, R. (2008). Consumption. Routledge.

Bourdieu P. (1984). Distinction: A Social Critique of the Judgment of Taste. Routledge.

Campbell, C. (1995). The Sociology of Consumption. In D. Miller (ed.), Acknowledging Consumption. (Chapter 3), Routledge. Campbell, C. (1987). The Romantic Ethic and the Spirit of Modern Consumerism, WritersPrintShop.

Castree, N. (2003). Place: connections and boundaries in an interdependent world. Key concepts in geography, 165-186.

Corbin, J., \& Strauss, A. (2015). Basics of Qualitative Research: Techniques and Procedures for Developing Grounded Theory. SAGE Publications Ltd.

Davoodi, E. (2013), The Role and Position of Third Places in Promoting Public Social Life in Zanjan, Unpublished Master Thesis in Urban Design at Islamic Azad University- Central Tehran Branch, Tehran [in Persian].

De Certeau, M. (1998). The Practice of Everyday Life, In Storey, J. (2018) Cultural theory and popular culture: An Introduction, Routledge.

Domosh, M. (1996). The feminized retail landscape: gender ideology and consumer culture in nineteenth-century New York City. Retailing, consumption and capital: Towards the new retail geography, 257-270.

Fainstein, S. S., \& Servon, L. J. (Eds.). (2005). Gender and planning: A reader. Rutgers University Press.

Featherstone, M. (1995). Undoing culture: Globalization, postmodernism and identity (Vol. 39). SAGE Publications Ltd.

Firat, A., Kutucuoglu, K. Y., Saltik, I. A., \& Tuncel, O. (2013). Consumption, consumer culture and consumer society. Journal of Community Positive Practices, (1), 182-203.

Friedman, J. (ed.). (1994). Consumption and Identity. Harwood Academic Press.

Giddens, A. (1991). Modernity and self-identity: Self and society in the late modern age. Stanford University Press.

Glennie, P. D., \& Thrift, N. J. (1992). Modernity, urbanism, and modern consumption. Environment and Planning D: Society and Space, 10(4), 423-443.

Goodman, M. K., Goodman, D. \& Redclift M. (Eds.). (2010). Consuming Space: placing consumption in perspective. Ashgate.

Hajizadeh M., Yusefi F. (2013). Investigation of some social factors related to consumer culture among women in Yazd. Strategic Studies of Women, (61), 233-271 [in Persian]. 
Urban consumption in modern Iran

Harvey D. (1989). The Condition of Postmodernity: An Enquiry into the Origins of Cultural Change. Wiley-Blackwell Jackson, J. H. (1997). The world trading system: law and policy of international economic relations. MIT press.

Jayne, M. (2006). Cities and consumption. Routledge.

Knox, P. L. (1987). The Social Production of the Built Environment: Architects, Architecture, and the Postmodern City. Progress in Human Geography, 21(3), 354-377.

Lunt, P. K., \& Livingstone, S. (1992). Mass consumption and personal identity: Everyday economic experience. Open University Press.

Massey, D., \& Massey, D. B. (2005). For space. SAGE Publications Ltd.

Miles, S. (2010). Spaces for consumption. SAGE Publications Ltd.

Miller, D. (ed.) (1995). Acknowledging Consumption. Routledge.

Mohammadpour A., Bahmani M. (2010). Women, shopping centers and Sign consumption. Strategic Studies of Women, (47), 41-72 [in Persian].

Sandhu, S. K., \& Paim, L. (2016). Consuming for status among Malaysian working women. Journal of Emerging Economies and Islamic research, 4(3), 11-16.

Scott A. J. (2000). The Cultural Economy of Cities: Essays on the Geographies Image Producing Industries. SAGE Publications Ltd.

Simmel, G. (1957). Fashion. American journal of sociology, 62(6), 541-558.

Slater, D. (1997). Consumer Culture and Modernity. Polity Press.

Soja, E. W. (1989). Postmodern geographies: The reassertion of space in critical social theory. Verso.

Thrift, N. (2003). Space: the fundamental stuff of geography. Key concepts in geography, 2, 95-107.

Urry, J. (1995). Consuming places. Routledge, in Jayne, M. (2006). Cities and consumption. Routledge.

Valentine, G. (1989). The geography of women's fear. Area, 385-390, in Jayne, M. (2006). Cities and consumption. Routledge.

Veblen, T. (1965). The theory of the leisure class. 1899. Augustus M Kelley Publishers.

Warde, A. (1997). Consumption, food and taste. SAGE Publications Ltd.

Zanjan municipality (2016). 2016 Statistics of the city of Zanjan. Nikan Ketab [in Persian].

Zanjan Road and Urban Development Organization (2019). Zanjan Comprehensive Plan. Naqshe mohit Consulting Engineers [in Persian].

Zokin S. (1982). Loft Living: Culture and Capital in Urban Change. Johns Hopkins University Press.

Editor: Rodrigo Firmino

Received: 14 Oct. 2019

Approved: 18 Feb. 2021 